\section{2}

\title{
Impact of the invasive painted bug Bagrada hilaris on physiological traits of its host Brassica oleracea var botrytis
}

\author{
Salvatore Guarino ${ }^{1,2} \cdot$ Ezio Peri $^{1} \cdot$ Stefano Colazza $^{1} \cdot$ Nicola Luchi $^{2}$. \\ Marco Michelozzi $^{3} \cdot$ Francesco Loreto $^{4}$
}

Received: 5 February 2016 / Accepted: 20 March 2017

(C) Springer Science+Business Media Dordrecht 2017
In particular, production of limonene was strongly reduced by the infestation of the two pentatomids, while an increase in the emission of acetic acid and 2-ethyl-1-hexanol was observed. EAG dose-response tests using the main plant VOC showed B. hilaris antennal responses to benzaldehyde, octanal, nonanal, and acetic acid, which indicates a role of these compounds in host location.

Keywords Bagrada hilaris $\cdot$ Nezara viridula . Photosynthesis - Stomatal conductance · Visual damage · Volatile organic compounds (VOC) $\cdot$ Electroantennography (EAG)

\section{Introduction}

Invasions by phytophagous insects are an important consequence of global change, as alien insects threaten indigenous species, and contribute to biodiversity loss, ecosystem degradation, and impairment of ecosystem services AQ1 3 worldwide (Kenis et al. 2009). Alien insects can affect native biodiversity through direct interactions, e.g., herbivore feeding on a native plant (Jenkins 2003), but also indirectly, e.g., competing for food or space with native species (Roques et al. 2009). However, the differences in terms of insect-plant interactions between invasive and local phytophagous pests have rarely been investigated (Paris et al. 2010).

It is well known that plants can respond to herbivore feeding by changing the emission of volatile organic compounds (VOC) at the quantitative or qualitative level, also producing "herbivore induced plant volatiles" (HIPV) (Dicke and Van Loon 2000). Changes in the VOC profile may be accompanied and/or associated with a change in the physiology of the host plant (Paré and Tumlinson

\begin{tabular}{|l|l|l|l|l|}
\hline Journal : Large 11829 & Article No : 9516 & Pages : 10 & MS Code : APIS-D-16-00014 & Dispatch : 25-3-2017 \\
\hline
\end{tabular}


1997; Holopaainen and; Gershenzon 2010). The feeding mechanism of phytophagous species (chewing or piercingsucking) also plays an important role in influencing host plant physiology (Welter 1989). In the case of true bugs (Hemiptera: Heteroptera), they penetrate plant tissues with stylet mouthparts and display different feeding behaviors classified as stylet sheath feeding, lacerate-and-flush feeding, macerate-and-flush feeding, and osmotic pump feeding (Hori 2000). Generally, these phytophagous insects cause less mechanical damage to leaves compared to chewing herbivores, and the overall impact on plant physiology is also reduced (Hare and Elle 2002). Nevertheless true bugs are also responsible for serious crop losses and are a major threat to agriculture worldwide because of their typical aggregation behavior on host plants and their potential to transmit pathogens (Schaefer and Panizzi 2000). In recent decades, the impact of true bug infestation on plants VOC emission was investigated in some plant-pentatomid systems (Williams et al. 2005; Velikova et al. 2010; Moujahed et al. 2014).

The painted bug, Bagrada hilaris Burmeister, is an invasive pentatomid species feeding mainly on brassicaceous hosts, and particularly dangerous to crop production in newly invaded areas (Huang et al. 2014). This pest, native to Asia and Africa, was first reported in Europe in 1978 in Pantelleria Island (Italy), and in Malta, where it feeds on Capparis spinosa L., caper bush (CAB 1981; Colazza et al. 2004). In Europe, B. hilaris has been so far confined to these two islands. In 2008, the painted bug was first reported in California, probably introduced by commercial trade, and rapidly expanded its range to the brassicaceous crops of coastal California and southwestern Arizona (Palumbo and Natwick 2010). Successively, it was reported in Nevada, New Mexico, and Utah (Bundy et al. 2012). More recently, B. hilaris has been observed in México (Sánchez-Peña 2014) and on the Big Island of Hawaii (Palumbo et al. 2016). Since its introduction in North America, B. hilaris had exerted a strong negative impact on agriculture; it has been estimated that about $90 \%$ of the broccoli acreage planted in USA has been infested by the painted bug, with yield losses often exceeding $10 \%$ of production (Huang et al. 2014). The bug damage appears as circular or star-shaped chlorotic spots on plant tissues that become necrotic (Palumbo et al. 2016).

Seedlings and young plants of several Brassica species are highly susceptible to feeding damage on cotyledons, newly emerged leaves, and apical meristems (Sánchez-Peña 2014), with significant reductions in leaf area, chlorophyll content, and dry weight (Huang et al. 2014).

The aggressiveness of this species poses questions about the real impact of the invasive $B$. hilaris feeding activity on physiology of Brassica host plants. The aim of this study was to investigate the effects of artificial $B$. hilaris infestation on Brassica oleracea var botrytis by measuring visual damage, photosynthesis, stomatal conductance, and plant VOC emissions. These aspects have been rarely investigated among pentatomids, e.g., on the harlequin bug Murgantia histrionica Hahn (Conti et al. 2008; Velikova et al. 2010). The effects of the invasive painted bug infestation were compared with those of Nezara viridula L., a pentatomid of African origin with a wide range of host plants, but long established in Europe and America. Finally, the potential role of plant volatile compounds in host location by $B$. hilaris was investigated by EAG dose-response tests.

\section{Materials and methods}

\section{Plants and insects}

Cauliflower seeds (B. oleracea $\mathrm{L}$. var botrytis, cv Alverda) were planted individually in plastic pots $(8 \times 8 \mathrm{~cm})$, filled with soil (COMPO BIO, Compo Italia srl, Italy). Cauliflowers were grown in a greenhouse at $20-25^{\circ} \mathrm{C}, 60-80 \%$ RH with a $16 / 8$ (light/dark) photoperiod. Plants were irrigated daily and fertilized with a $1 \mathrm{~g} \mathrm{l}^{-1}$ solution of Flory 9 Hydro (N-P-K 15-7-22) (Planta Regenstauf). Forty days after planting, seedlings were selected for dimensional uniformity. Selected plants were moved to a $(4 \times 6 \times 2 \mathrm{~m})$ walkin growth chamber programmed with $16-\mathrm{h}$ photoperiod, photosynthetic photon flux density (PPFD) of $600 \mu \mathrm{mol}$ photons $\mathrm{m}^{-2} \mathrm{~s}^{-1}$ at the top of the foliage, $\mathrm{CO}_{2}$ concentration of $420 \mu \mathrm{mol} \mathrm{mol}{ }^{-1}, 24 \pm 2{ }^{\circ} \mathrm{C}$ temperature, and $65 \%$ relative humidity. Plants were acclimated to the climatic conditions of the chamber for 2 days before insect infestation. Plants with 6-7 expanded leaves were used for the experiments.

Insect species were reared in an environmentally controlled room $\left(25 \pm 1^{\circ} \mathrm{C}, 70 \pm 10 \% \mathrm{RH}\right.$, photoperiod 16L:8D), inside wooden cages $(25 \times 25 \times 40 \mathrm{~cm})$ with two $5-\mathrm{cm}$ diameter mesh-covered holes for ventilation. The colony of $B$. hilaris was established and restocked regularly with insects collected from caper fields (C. spinosa) located in the island of Pantelleria (Italy). The insect colony was provided with cauliflower, cole-seed, and cabbage plants, depending on seasonal availability. As B. hilaris lays eggs in the soil, dishes $(6-\mathrm{cm} \varnothing)$ with a mixture of sand, silt, and clay (33\% for each soil component) were placed inside the cages to allow oviposition. Dishes were changed weekly, and those with glued eggs were kept in separated cages until emergence of nymphs.

Similarly, a colony of $N$. viridula was established from locally collected individuals. Insects were fed with sunflower seeds and seasonal fresh vegetables. For both insect species, separate rearing cages were used for nymphs and adults. Adults used for the experiments were randomly selected among individuals 5-10 days old.

\begin{tabular}{|l|l|l|l|l|}
\hline Journal : Large 11829 & Article No : 9516 & Pages : 10 & MS Code : APIS-D-16-00014 & Dispatch : 25-3-2017 \\
\hline
\end{tabular}




\section{Plant damage}

The impact of $B$. hilaris and $N$. viridula feeding activity on host plants was investigated in terms of change of ecophysiological parameters and visual damage. Impact on photosynthesis and stomatal conductance was evaluated by infesting a single $B$. oleracea plant placed in a Plexiglass cage $(40 \times 40 \times 40 \mathrm{~cm})$ with the ceiling made of net for ventilation. The following treatments were made: (a) plants infested with 15 adults of B. hilaris $(N=6)$; (b) plants infested with 40 adults of $B$. hilaris $(N=6)$; (c) plants infested with 15 adults of $N$. viridula $(N=6)$; (d) healthy plants $(N=8)$. Sex ratio of individuals used for this experiment was 1:1. Plants were infested for $24 \mathrm{~h}$ in the growth chamber in an environmentally controlled room maintained at $25 \pm 1{ }^{\circ} \mathrm{C}, 70 \pm 10 \% \mathrm{RH}$, photoperiod of 16:8 (light:dark). Immediately before measuring ecophysiological parameters, the insects were removed from the infested plant using an artist's paintbrush. Gas exchanges were measured using the LI-6400 portable photosynthesis system (Li-Cor, Lincoln, NE, USA). A portion $\left(6 \mathrm{~cm}^{2}\right)$ of the leaf area was clamped in the gasexchange cuvette and exposed to a $0.441 \mathrm{~min}^{-1}$ flow of synthetic air, contaminant-free, and made by mixing $\mathrm{N}_{2}$ (80\%), $\mathrm{O}_{2}(20 \%)$ and $400 \mathrm{ppm} \mathrm{CO}_{2}$. Air humidity was set at $45-55 \%$, PPFD at $800 \mu \mathrm{mol} \mathrm{m} \mathrm{m}^{-2} \mathrm{~s}^{-1}$, and air temperature inside the cuvette at $25^{\circ} \mathrm{C}$. Photosynthesis (A), stomatal conductance $\left(\mathrm{g}_{\mathrm{s}}\right)$, and intercellular $\mathrm{CO}_{2}$ concentration $\left(\mathrm{C}_{\mathrm{i}}\right)$ were calculated using the LI-6400 software.

In order to compare visual damage, i.e., the area of foliar discolored spots caused by feeding of $B$. hilaris and $N$. viridula individuals, experiments were carried out in Petri dishes. A single B. oleracea leaf (mean surface $15.15 \pm 1.00 \mathrm{~cm}^{2}$ ) was cut at the base of the petiole, which was inserted in a 2-ml vial filled with water-soaked cotton to maintain turgidity, and placed in a plastic Petri dish $(10-\mathrm{cm} \varnothing)$ with $5-\mathrm{cm} \varnothing$ mesh-covered holes on the lid for ventilation. Only females were used for this bioassay, as previous studies on $B$. hilaris revealed that females feed for significantly longer periods, and cause almost fivefold more damage than males (Huang et al. 2014). A single randomly selected female of $B$. hilaris or $N$. viridula was gently placed inside the Petri dish using a paintbrush. Females were food deprived for $24 \mathrm{~h}$ before the experiment. The bioassays were conducted in a climatic room at conditions of $25 \pm 1{ }^{\circ} \mathrm{C}, 70 \pm 10 \% \mathrm{RH}, 16: 8$ photoperiod. After $24 \mathrm{~h}$, insects were removed and the size (in $\mathrm{mm}^{2}$ ) of each single discolored spot induced from $B$. hilaris or $N$. viridula individuals was estimated by measuring the areas under a stereomicroscope with the help of a transparent graph paper sheet (Tecnopen - DQ, Buffetti, Roma, Italy). Twelve replicates were conducted per treatment.

\section{VOC emission}

Plants used to estimate the ecophysiological parameters were also used for volatile collection immediately after measuring photosynthesis and stomatal conductance. To measure VOC emissions, the outlet of the gas-exchange cuvette was disconnected from the LI-6400 system, and the flow was diverted into a cartridge packed with $30 \mathrm{mg}$ of Tenax TA and $30 \mathrm{mg}$ of Carboxen 1000 (SRA Intruments, Cernusco sul Naviglio, Milano, Italy). A volume of 51 of air was pumped through the trap at a rate of 0.31 $\min ^{-1}$. The cartridge was stored in a refrigerator until analysis by GC-MS, using an Agilent 7820 GC equipped with a $5975 \mathrm{C}$ MSD with EI ionization (Agilent Technologies, Wilmington, DE). A Gerstel MPS2 XL autosampler equipped with automated Thermal Desorption Unit (TDU) and liquid $\mathrm{CO}_{2}$-cooled programmable temperature vaporizer (GERSEL CIS 4) was used for ensuring consistent VOC extraction and injection conditions. The following chromatographic settings were used: injector in splitless mode set at $260^{\circ} \mathrm{C}$; J\&W Innowax column $(30 \mathrm{~m}, 0.25 \mathrm{~mm}$ i.d., $0.5 \mu \mathrm{m} \mathrm{df}$ ); oven temperature program starting with an initial temperature of $40^{\circ} \mathrm{C}(1 \mathrm{~min})$, then ramping at $5^{\circ} \mathrm{C}$ $\min ^{-1}$ until $200^{\circ} \mathrm{C}$, at $10^{\circ} \mathrm{C} \min ^{-1}$ until $220^{\circ} \mathrm{C}$, and at $30^{\circ} \mathrm{C} \mathrm{min}^{-1}$ until $260^{\circ} \mathrm{C}$, and hold time at the highest temperature of $3 \mathrm{~min}$. Helium was used as carrier gas at $1 \mathrm{ml}$ $\min ^{-1}$. The MS detector was operated in scan mode in the $\mathrm{m} / \mathrm{z}$ range $29-330$, at three scans $\mathrm{s}^{-1}$. Synthetic standards provided from Sigma-Aldrich (Milan, Italy) were used for chemical identification.

\section{Electroantennography}

Electroantennogram (EAG) dose-response recordings were conducted with the main VOC identified in the previous experiment: $(R)$-limonene, $(S)$-limonene, octanal, nonanal, decanal, benzaldehyde, acetic acid. All used VOC where $\geq 95 \%$ purity, obtained from Sigma-Aldrich (Milan, Italy). VOC were serially diluted 1:10 with hexane (SigmaAldrich, HPLC-grade, 99\%) up to the concentration of $1 \mu \mathrm{g} 11^{-1}$. For EAG experiments, a standard $1 \mu \mathrm{l}$ aliquot of each test solution was pipetted onto a piece of filter paper (Whatman, grade 1), exposed to the air for $30 \mathrm{~s}$ to allow the solvent to evaporate, and then inserted into a glass Pasteur pipette. Puff stimuli were blown across insects' antennae using a flow controller (model CS-05; Syntech, Hilversum, The Netherlands) to generate a 1.5-s stimulus at 1-min interval, with a flow rate of $1.51 \mathrm{~min}^{-1}$. The signals generated by the antennae were passed through a high-impedance amplifier (model IDAC-4, Syntech) and recorded with specialized software (Syntech). At the beginning and the end of the stimulation of the antennae with each concentration of the compounds, $1 \mu$ pure hexane was puffed

\begin{tabular}{|l|l|l|l|l|}
\hline Journal : Large 11829 & Article No : 9516 & Pages : 10 & MS Code : APIS-D-16-00014 & Dispatch : 25-3-2017 \\
\hline
\end{tabular}


as reference. Tested compounds were used for each active ingredient, using the amounts of $1,10,100$, and $1000 \mu \mathrm{g}$. The sequence of the stimuli of all the compounds was provided starting from the lowest dose. The same antenna was used to test all the concentrations of a single compound. The response elicited from hexane (mean of the two puffs) was subtracted from the responses obtained by the test stimuli. Each dose of the chemicals was tested on one randomly selected antenna per insect $(N=14$; sex ratio $1: 1)$. Bagrada hilaris adults were anesthetized by refrigerating them at about $-4^{\circ} \mathrm{C}$ for approximately $40 \mathrm{~s}$. They were cut between head and prothorax. The anterior part (constituted by antennae and head) was used for the recordings. EAG connections were made by inserting the cut end of the head into a glass capillary $(1.5 \mathrm{~mm}$ diameter) grounding electrode in contact with a silver wire, filled with $0.1 \mathrm{M}$ $\mathrm{KCl}$ solution. The recording electrode was a similar glass capillary brought into contact with the distal cut end of the antenna. The capillary tubes were drawn to a fine point using a microelectrode puller (Narishige PC-10, Japan) to get an inner diameter wide enough to enable insertion of the preparation.

\section{Statistical analysis}

Mean values of photosynthesis and stomatal conductance were analyzed by one-way ANOVA and statistically separated by Tukey test. The mean surface of foliar discolored spots caused by B. hilaris and $N$. viridula feeding was compared by a $t$ test for independent samples. VOC data were subjected to root square transformation and then analyzed by one-way ANOVA. The EAG responses of the adults to the different doses of each chemical were analyzed by repeated measures ANOVA with dose and chemical (VOC) as independent variables. Within each chemical, mean EAG responses were separated using least significant difference tests. Since both sexes of $B$. hilaris showed similar EAG responses $\left(F_{1,84}=1.32 ; P=0.25\right.$; ANOVA), data from males and females were pooled together. All the statistical analyses were performed using Statistica 7.0 for Window (Statsoft 2001, Vigonza, PD, Italy).

\section{Results}

\section{Plant damage}

The infestation with 15 adult individuals of $B$. hilaris and $N$. viridula reduced photosynthesis by about 25 and $15 \%$, respectively. However, these reductions were not statistically significant when compared to rates of healthy plants (Fig. 1a). The infestation with 40 individuals of $B$. hilaris determined a statistically significant reduction of
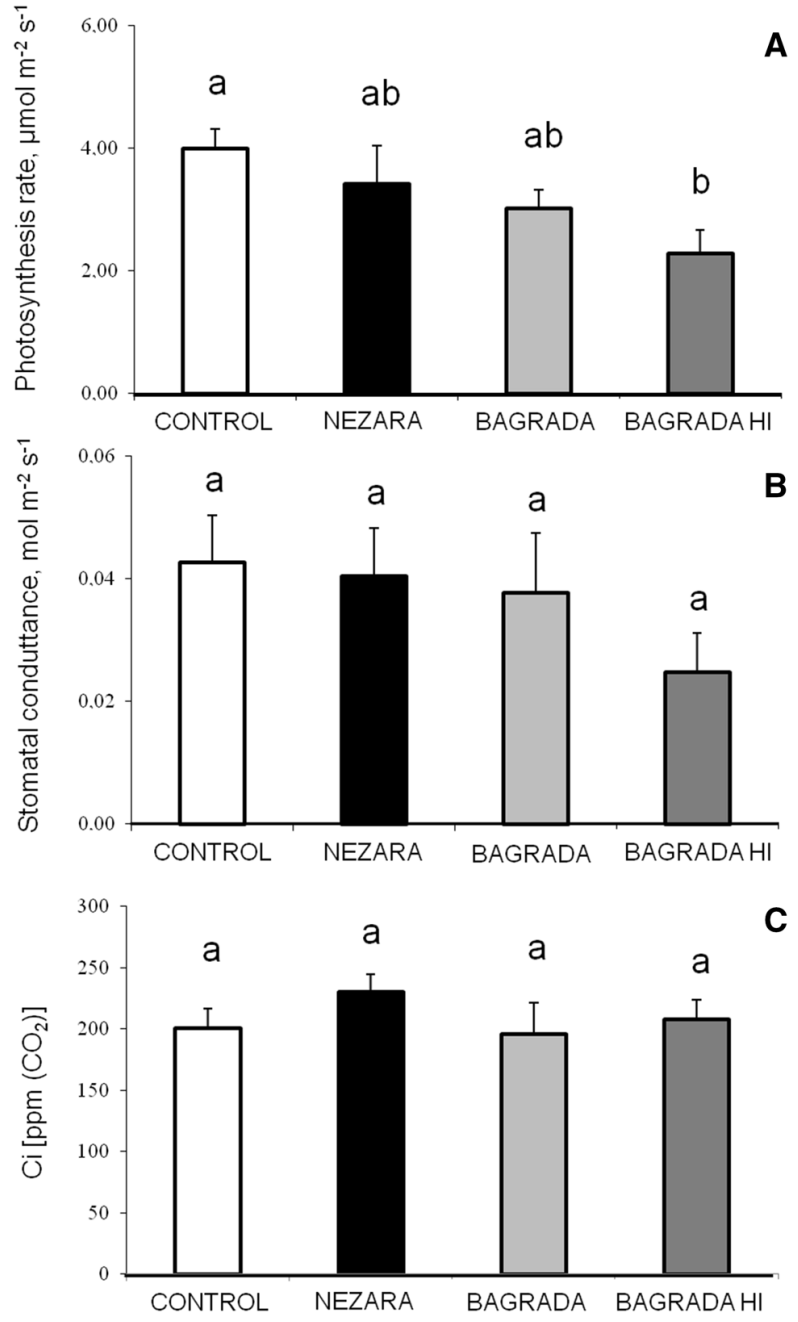

Fig. 1 Photosynthesis (a), stomatal conductance (b), and intercellular $\mathrm{CO}_{2}$ concentration (c) of Brassica oleracea var botrytis leaves after a 24-h long exposure to $B$. hilaris (15 adults) (BAGRADA), B. hilaris (40 adults) (BAGRADA $\mathrm{HI}), N$. viridula (15 adults) (NEZARA), or healthy plants (CONTROL). Mean values \pm SE are given. Different letters indicate significant $(P<0.05)$ differences as evaluated by ANOVA and Tukey test

photosynthesis by about $43 \%$ compared to healthy plants $\left(F_{3,22}=3.13, P<0.05\right.$; ANOVA). The infestation with 15 adult individuals of $B$. hilaris and $N$. viridula caused a small reduction of stomatal conductance, whereas the infestation with 40 individuals of $B$. hilaris caused a $43 \%$ reduction of the stomatal conductance compared to healthy plants (Fig. 1b). However, even the latter was not statistically significant due to the large variability between measurements $\left(F_{3,22}=1.02, P=0.39\right.$; ANOVA $)$. The mean $( \pm \mathrm{SE})$ values of intercellular $\mathrm{CO}_{2}$ concentration $(\mathrm{Ci})$ [ppm $\left.\left(\mathrm{CO}_{2}\right)\right]$ were, respectively, $200 \pm 15$ in healthy plants, $195 \pm 27$ in plants infested with 15 individuals of B. hilaris, $230 \pm 14$ in plants infested with 15 individuals of $N$. viridula, and $207 \pm 16$ in

\begin{tabular}{|l|l|l|l|l|}
\hline Journal : Large 11829 & Article No : 9516 & Pages : 10 & MS Code : APIS-D-16-00014 & Dispatch : 25-3-2017 \\
\hline
\end{tabular}


plants infested with 40 individuals of $B$. hilaris, with no significant differences among treatments (Fig. 1c).

Visual damage was significantly greater when caused by individual females of $B$. hilaris than by $N$. viridula. The area of discolored spots determined after a 24 -h feeding on a single leaf was, respectively, $9.58 \pm 2.67 \mathrm{~mm}^{2}$ for B. hilaris and $2.62 \pm 1.14 \mathrm{~mm}^{2}$ for $N$. viridula (mean $\pm \mathrm{SE}$; $t=2.16 ; d f=20 ; P=0.046)$.

\section{VOC emission}

Volatile blends of infested and healthy plants are shown in Fig. 2. Twelve VOC were identified by GC-MS analysis. There was no qualitative variation in the volatile emissions from healthy plants and bug-infested plants. Major volatile compounds were generally limonene, nonanal, acetic acid, and decanal. The infestation of the host plant with $B$. hilaris or $N$. viridula individuals affected significantly the quantity of volatile emissions of decanal, 2-ethyl-1-hexanol, acetic acid, nonanal, and limonene. Bug-infested plants emitted a significantly lower amount of limonene compared to healthy plants $\left(F_{3,21}=5.19 ; P<0.02\right.$; ANOVA). Plants infested with 40 individuals of $B$. hilaris also emitted significantly higher amounts of acetic acid than healthy plants $\left(F_{3,21}=2.20 ; \quad P=0.03 ; \quad\right.$ ANOVA $)$. Significantly higher amounts of 2-ethyl-1-hexanol were detected in plant infested with 40 individuals compared to plants infested with 15 individuals of $B$. hilaris $\left(F_{3,21}=1.45 ; P<0.05\right.$; ANOVA), while no differences were observed in comparison to healthy controls and plants attacked by $N$. viridula. Plants infested with 15 individuals of $B$. hilaris emitted significantly less decanal than plants infested with 15 individuals of $N$. viridula $\left(F_{3,21}=1.57 ; P<0.05\right.$; ANOVA), while no differences were observed with healthy plants. The amounts of all the other VOC did not differ statistically among the treatments.

\section{Electroantennography}

Antennae of B. hilaris adults showed positive dosedependent responses to four out of the seven VOC tested: benzaldehyde, octanal, nonanal, and acetic acid (Fig. 3). Significant differences in EAG responses were observed among chemicals $\left(F_{6,84}=5.05 ; P<0.001 ;\right.$ ANOVA $)$ and among doses $\left(F_{3,252}=19.85 ; P<0.001\right.$; ANOVA $)$. Also the interaction of the two factors provided a statistically significant effect $\left(\mathrm{F}_{18.252}=5.43 ; P<0.001\right)$. Significant EAG responses were already recorded at the dose of $10 \mu \mathrm{g}$ for octanal $\left(F_{3,36}=7.72 ; P<0.001\right.$; ANOVA $)$ and benzaldehyde $\left(F_{3,36}=10.48 ; P<0.001\right.$; ANOVA), while significant responses starting at the dose of $100 \mu \mathrm{g}$ were determined for nonanal $\left(F_{3,36}=2.97 ; P<0.01\right.$; ANOVA $)$ and acetic $\operatorname{acid}\left(F_{3,36}=8.36 ; P<0.05\right.$; ANOVA $)$.

\section{Discussion}

The feeding activity of B. hilaris not only determines damage that is visible immediately, but also influences ecophysiology and VOC emission of B. oleracea var. botrytis leaves. Feeding damage by pentatomids is determined by salivary secretions, considered phytoaggressive as enzymatically dissolve plant tissues and/or cause subsurface corking damage on plant tissues (Wiman et al. 2014 and reference therein). Our visual damage experiment indicated that single $B$. hilaris individuals, despite their smaller size compared to $N$. viridula, caused a greater amount of discolored spots after feeding. Whether this is due the injection of toxins that degrade chlorophylls or to the different feeding habit is not known. Bagrada hilaris feeds by a lacerate-and-flush method, in a way that the repetitive insertion of stylets between leaf epidermal layers causes mechanical damage to cellular tissue (Reed et al. 2013). On the other hand, $N$. viridula adults feed on leaf veins with a stylet sheath feeding mode destroying only a few cells and causing minimal mechanical damage (Miles 1972; Hori 2000). According to the generalist/specialist hypothesis, host plant defenses affect mainly the polyphagous species rather than the specialist ones (Van der Meijden 1996; Agrawal 2000; Ali and Agrawal 2012). In the case of brassicaceous plants, glucosinolates are reported to reduce the performance of generalist herbivores, while acting as feeding/oviposition stimulants for specialists (Fahey et al. 2001; Halkier and Gershenzon 2006; Hopkins et al. 2009; Müller et al. 2015). Consequently, the different host specificity of the two species could explain our results; in fact while $N$. viridula is polyphagous and feeds on members of many plant families, B. hilaris is more associated with brassicaceous plants.

Our results also show that the number of individuals infesting the plant was proportional to the damage inflicted. Only infestations by 40 individuals/plant of $B$. hilaris determined a remarkable reduction of leaf photosynthesis. In the case of pierce-sucking insects, including pentatomid species, the damage is often strictly related to the number of individuals that feed on the plant, as reported for M. histrionica (Ludwig and Kok 2001), and for cauliflower and other different Brassica species infested by $B$. hilaris adults (Huang et al. 2014). Field observations indicate that $B$. hilaris often forms large aggregations of hundreds of both adult individuals and immature stages on infested plants, probably mediated by intra- and inter-specific semiochemicals (Guarino et al. 2008; Reed et al. 2013). Given that the single individual can produce more damage than other pentatomid species, as demonstrated above, infestations of B. hilaris may cause heavy plant damage and crop losses. However, the small size of $B$. hilaris adults compared to $N$. viridula might reduce damage at the ecophysiological level.

\begin{tabular}{|l|l|l|l|l|}
\hline Journal : Large 11829 & Article No : 9516 & Pages : 10 & MS Code : APIS-D-16-00014 & Dispatch : 25-3-2017 \\
\hline
\end{tabular}




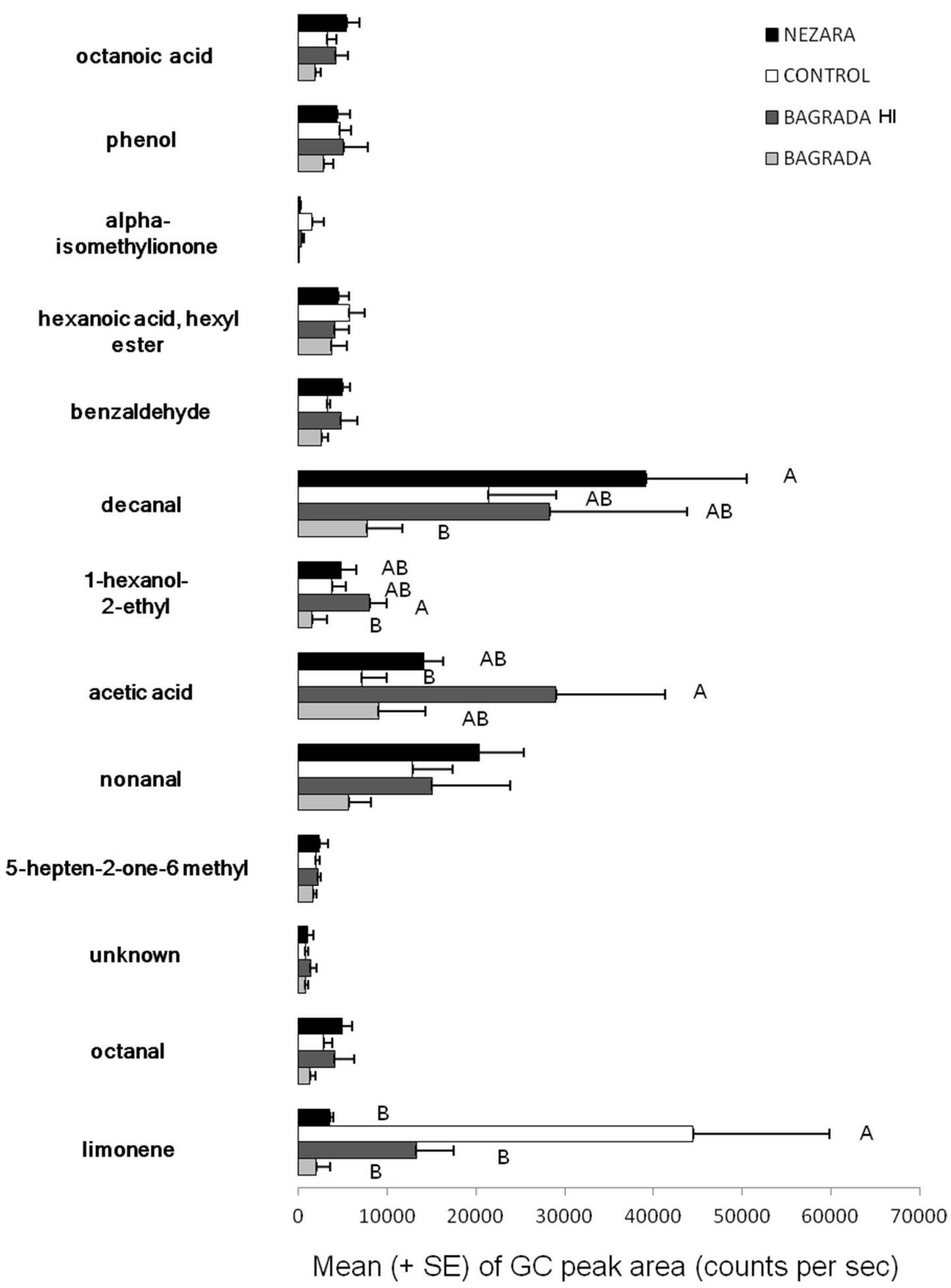

Fig. 2 Volatile (VOC) blend composition of the B. oleracea var botrytis leaves after a 24-h long exposure to B. hilaris (15 adults) (BAGRADA), B. hilaris (40 adults) (BAGRADA HI), N. viridula (15 adults) (NEZARA), or healthy plants (CONTROL). Bars indicate the mean amount $\pm \mathrm{SE}$ of each compound. Different letters indicate significant $(P<0.05)$ differences as evaluated by ANOVA and LSD test

\begin{tabular}{|l|l|l|l|l|}
\hline Journal : Large 11829 & Article No : 9516 & Pages : 10 & MS Code : APIS-D-16-00014 & Dispatch : 25-3-2017 \\
\hline
\end{tabular}




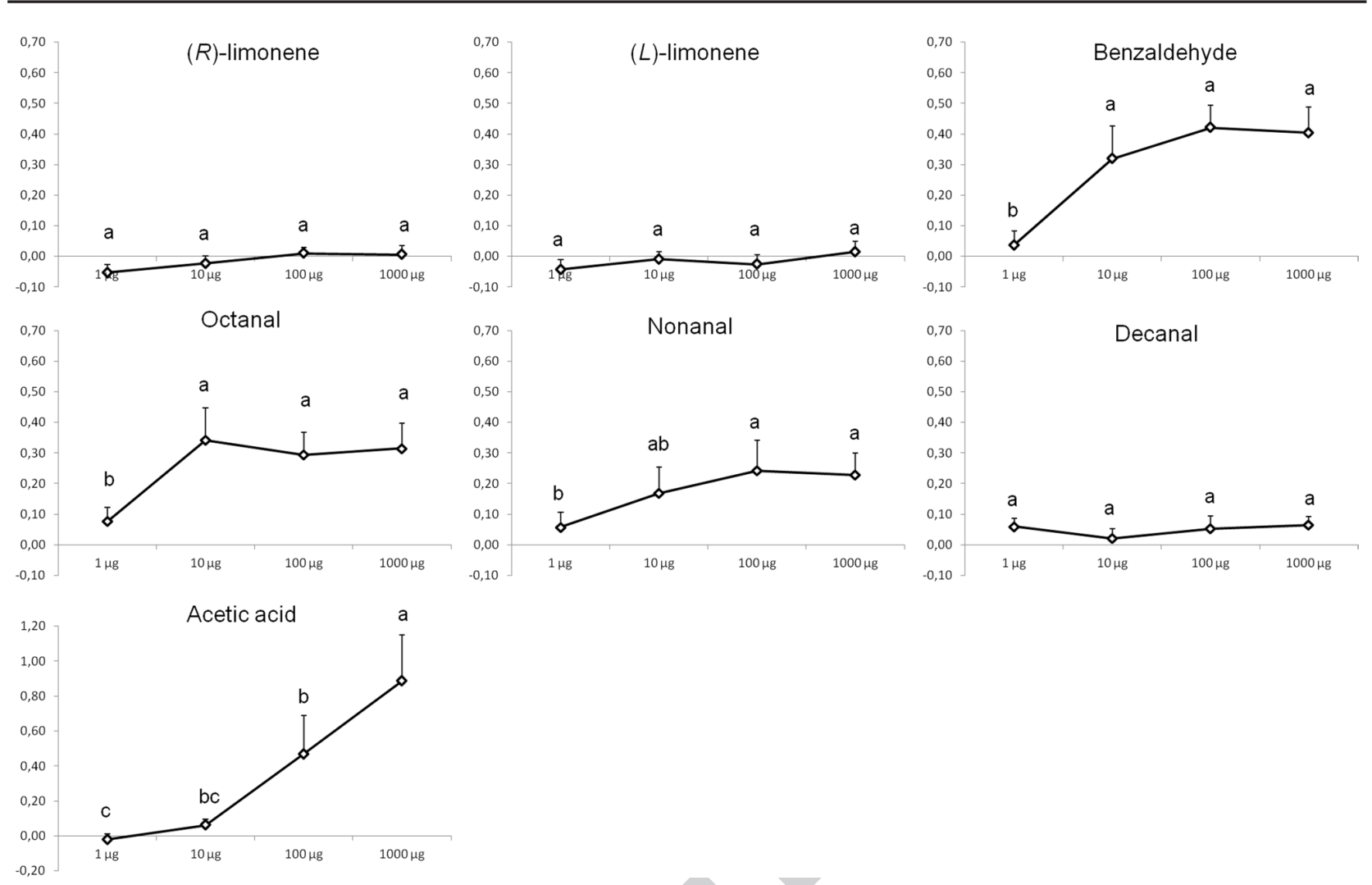

Fig. 3 EAG dose-response curves of $B$. hilaris adults to VOC of B. oleracea var botrytis leaves. EAG amplitudes were adjusted to a control stimulus (hexane). Different letters indicate that values differ statistically at $P<0.05$ (Repeated measures ANOVA, followed by Fisher LSD test)

Huang et al. (2014) observed a strong reduction of chlorophyll content, and a reduction of leaf growth, in brassica plants infested by B. hilaris adults. Velikova et al. (2010) showed a significant reduction of photosynthesis in cabbage plants infested by $M$. histrionica and in broad bean plants infested by $N$. viridula. The same study showed that the permanent reduction of photosynthesis was due to the damage of photochemical reactions associated to chlorophyll loss. Photosynthesis might be solely limited by photochemical reactions also in $B$. oleracea infested by $B$. hilaris, as indicated by discolored areas associated to chlorophyll degradation. Stomatal closure, albeit not limiting photosynthesis, might indicate down-regulation of gas exchange, which leads to reduced water loss by crop transpiration, an issue that should be carefully investigated.

Infestation by $B$. hilaris and $N$. viridula adults resulted in some quantitative changes of VOC emission as compared to emission by healthy $B$. oleracea plants. However, as also stated by other authors, the changes of VOC emission in response to piercing-sucking insect infestations can be low and at times undetectable (Du et al. 1998; Turlings et al. 1998). In the present work, the emission of limonene, representing the main component of the VOC blend emitted by healthy plants, was significantly reduced in infested plants.
Monoterpenes, such as limonene, generally accumulate in specific plant tissues where they have constitutive defensive functions (Gershenzon and Croteau 1991). Temporary pools of monoterpenes that are not associated with reservoirs, such as those found in $B$. oleracea plants, may also play a protective role, e.g., against heat stress (Loreto et al. 1998) or oxidative stress (Loreto et al. 2004). Monoterpene synthesis is induced by mammal herbivore attack (Litvak and Monson 1998), insect damage (Paré and Tumlinson 1997), and other biotic and abiotic causes of wounding (Lewinsohn et al. 1991). The reduction of limonene synthesis observed in our experiment is therefore somehow surprising and difficult to explain. Monoterpenes are formed by carbon branching directly from photosynthesis in the chloroplast (Loreto et al. 1996). Therefore, impairment of photosynthesis induced by $B$. hilaris infestation might also have reduced the carbon available for the synthesis of the main monoterpenes. Among the other VOC, emission of acetic acid was largely increased in plants strongly infested by B. hilaris adults. Release of oxygenated VOC is attributed to enzymatic oxidation of foliar fatty acids by lipoxygenases (Hatanaka 1993). This is generally induced by wounding, and limited to C6 oxygenated compounds, collectively called green leaf volatiles (GLV) (Loreto

\begin{tabular}{|l|l|l|l|l|}
\hline Journal : Large 11829 & Article No : 9516 & Pages : 10 & MS Code : APIS-D-16-00014 & Dispatch : 25-3-2017 \\
\hline
\end{tabular}


et al. 2006). However, especially under anoxic conditions, or after light-dark transitions, release of $\mathrm{C} 2$ compounds (methanol, acetic acid) may also occur (Jardine et al. 2012). Acetic acid emission could also be independent of plant metabolism, rather being associated with the higher presence of microorganism on plants heavily infested by $B$. hilaris as observed on other plants infested by other piercesucking insect species (Franke et al. 1999). Among GLV, only 2-ethyl-1-hexanol was found in higher amount in plants highly infested with $B$. hilaris. As briefly explained above, the increase of this fatty alcohol, common in other Brassica species (Barros et al. 2014), could indicate a damage occurring at plant membrane lipids. For example, GLV are induced by biotic stress factors such as herbivores (Mattiacci et al. 1994; Ruther et al. 2002; Williams et al. 2005). However, we note that 2-ethyl-1-hexanol is the only GLV induced by $B$. hilaris feeding. Remarkably, GLV that are produced in the early steps of fatty acid degradation (e.g., hexanol and hexenol) were not found in the blend emitted by infested plants. Similar results were obtained with other piercing-sucking insects feeding on different plant species. For example, broad bean plants infested by the pea aphid, Acyrthosiphon pisum (Harris), and maize plants infested by Rhopalosiphum maidis (Fitch) did not produce higher levels of GLV, even when infestation levels were heavy (Du et al. 1998; Turlings et al. 1998). The scarce induction of GLV in B. oleracea plants infested by B. hilaris and $N$. viridula infestation could be explained by a low mechanical damage associated with the feeding strategy of these insects, insufficient to activate the lipoxygenase pathway.

Some of the VOC identified in this study were perceived by the $B$. hilaris antennae in EAG bioassays, such as benzaldehyde, octanal, nonanal, and acetic acid. In particular, these compounds elicited increasing EAG response at increasing doses. A higher sensitivity was found for benzaldehyde and octanal, as these compounds were detected by the insect at the dose of $10 \mu \mathrm{g}$, while nonanal and acetic acid were only detected at $100 \mu \mathrm{g}$. The sensitivity of $B$. hilaris to benzaldehyde, octanal, nonanal, and acetic acid could indicate a role of these compounds in host detection. In fact, these molecules have been reported in the VOC profile of several B. hilaris host plants such as mustard Brassica juncea (Coss.) (Zhao et al. 2007), oliseed rape Brassica napus L. (Müller et al. 2002), and caper bush $C$. spinosa (Romeo et al. 2007). The use of plant volatiles for host location and recognition depends on insect ability to process olfactory signals. This is a difficult task in a natural environment, where insects are exposed to many different volatile chemicals, at different concentrations and in different combinations (Bruce et al. 2005; Schroeder and Hilker 2008). Finally, the lack of EAG response to limonene suggests that this monoterpene is not involved in plant-insect communication. Although monoterpenes serve primarily as chemical defenses against insects and diseases, these compounds may be also degraded and recycled back into primary compounds when there is a demand (Gershenzon 1993). Limonene might have been catabolized providing a carbon source for other processes, including production of VOC directly involved in plant response to insect attack.

To summarize, our results suggest that photosynthesis of $B$. oleracea plants is sensitive to infestation by numerous individuals of B. hilaris, which may impair leaf functionality and crop productivity. This is accompanied by a change of the constitutive emission of several VOC, some of which are perceived by insect antennae, suggesting a role in host location.

Acknowledgements The authors are grateful to Dr. David Hall for reviewing an early draft of the manuscript and to Dr. Gabriele Cenc- $\mathbf{A Q} 3$ etti for his helpful assistance during the GC-MS analysis. This work was supported by the Italian Ministry of Education, University and Research, within the Project "Assessing the impacts of invasive fungal pathogens and phytophagous insects on native plants, pathogens, phytophagous insects and symbionts" (FIRB 2012 - Programma "Futuro in Ricerca" 2012 - RBFR128ONN).

\section{References}

Agrawal AA (2000) Specificity of induced resistance in wild radish: causes and consequences for two specialist and two generalist caterpillars. Oikos 89:493-500

Agrawal AA, Kurashige NS (2003) A role for isothiocyanates in plant resistance against the specialist herbivore Pieris rapae. J Chem Ecol 29:1403-1415

Ali JG, Agrawal AA (2012) Specialist versus generalist insect herbivores and plant defense. Trends Plant Sci 17:293-302

Barros AF, Campos VP, da Silva JCP, Pedroso MP, Medeiros FHV, Pozza EA, Reale AL (2014) Nematicidal activity of volatile organic compounds emitted byBrassica juncea, Azadirachta indica, Canavalia ensiformis, Mucuna pruriens and Cajanus cajan against Meloidogyne incognita. Appl Soil Ecol 80 :34-43

Bruce TJA, Wadhams LJ, Woodcock CM (2005) Insect host location: a volatile situation. Trends Plant Sci 10:269-274

Bundy CS, Grasswitz TR, Sutherland C (2012) First report of the invasive stink bug Bagrada hilaris (Burmeister) (Heteroptera: Pentatomidae) from New Mexico, with notes on its biology. Southwest Entomol 37:411-412

CAB International (1981) Bagrada hilaris. Distribution map. Distribution Maps of Plant Pests. Map 417

Colazza S, Guarino S, Peri E (2004) Bagrada hilaris (Burmeister) (Heteroptera: Pentatomidae) fitofago dannoso al cappero nell'isola di Pantelleria. Inf Fitopatol 12:30-34

Conti E, Zadra C, Salerno G, Leombruni B, Volpe D, Frati F, Marucchini C, Bin F (2008) Changes in the volatile profile of Brassica oleracea due to feeding and oviposition by Murgantia istrionica (Heteroptera: Pentatomidae). Eur J Entomol 105:839-847

Dicke M, Van Loon JJA (2000) Multitrophic effect of the herbivoreinduced plant volatile in a evolutionary context. Ent Exp Appl 97:237-249

Du Y, Poppy GM, Powell W, Pickett JA, Wadhams LJ, Woodcock CM (1998) Identification of semiochemicals released during aphid feeding that attract parasitoid Aphidius ervi. J Chem Ecol $24: 1355-1368$

\begin{tabular}{|l|l|l|l|l|}
\hline Journal : Large 11829 & Article No : 9516 & Pages : 10 & MS Code : APIS-D-16-00014 & Dispatch : 25-3-2017 \\
\hline
\end{tabular}


Fahey JW, Zalcmann AT, Talalay P (2001) The chemical diversity and distribution of glucosinolates and isothiocyanates among plants. Phytochemistry 56:5-51

Franke H, Fegan M, Hayward C, Leonard G, Stackebrandt C, Sly LI (1999) Description of Gluconacetobacter sacchari sp. nov., a new species of acetic acid bacterium isolated from the leaf sheath of sugar cane and from the pink sugar-cane mealy bug. Int J Syst Evol Microbiol 49:1681-1693

Gershenzon J (1993) The cost of plant chemical defenses against herbivory: a biochemical perspective. In: Bernays EA (ed) Insectplant interactions, vol 5. CRC Press, Boca Raton, pp 105-173

Gershenzon J, Croteau R (1991) Terpenoids. In: Rosenthal GA, Berenbaum MR (eds) Herbivores, their interactions with secondary metabolites. Academic Press, New York, pp 169-219

Guarino S, De Pasquale C, Peri E, Alonzo G, Colazza S (2008) Role of volatile and contact pheromones in the mating behaviour of Bagrada hilaris (Heteroptera: Pentatomidae). Eur J Entomol 105:613-617

Halkier BA, Gershenzon J (2006) Biology and biochemistry of glucosinolates. Annu Rev Plant Biol 57:303-333

Hare JD, Elle E (2002) Variable impact of diverse insect herbivores on dimorphic Datura wrightii. Ecology 83:2711-2720

Hatanaka A (1993) The biogeneration of green odour by green leaves. Phytochemistry 34:1201-1218

Holopainen JK, Gershenzon J (2010) Multiple stress factors and the emission of plant VOCs. Trends Plant Sci 15:176-184

Hopkins RJ, van Dam NM, van Loon JJ (2009) Role of glucosinolates in insect-plant relationships and multitrophic interactions. Annu Rev Entomol 54:57-83

Hori K (2000) Possible causes of disease symptoms resulting from the feeding of phytophagous Heteroptera. Heteroptera of economic importance. CRC Press, Boca Raton, pp. 11-36

Huang TI, Reed DA, Perring T, Palumbo JC (2014) Feeding damage by Bagrada hilaris (Hemiptera: Pentatomidae) and impact on growth and chlorophyll content of Brassicaceous plant species. Arthropod Plant Interact 8:89-100

Jardine K, Barron-Gafford GA, Norman JP, Abrell L, Monson RK, Meyers KT, Pavao-Zuckerman M, Dontsova K, Kleist E, Werner C, Huxman TE (2012) Green leaf volatiles and oxygenated metabolite emission bursts from mesquite branches following light-dark transitions. Photosynth Res 113:321-333

Jenkins MA (2003) Impact of the balsam woolly adelgid (Adelges piceae Ratz.) on an Abies fraseri (Pursh) Poir. dominated stand near the summit of Mount LeConte, Tennessee. Castanea 68:109-111

Kenis M, Auger-Rozenberg MA, Roques A, Timms L, Péré C, Cock MJW, Settele J, Augustin S, Lopez-Vaamonde C (2009) Ecological effects of invasive alien insects. Biol Invasions 11:21-45

Lewinsohn E, Gijzen M, Croteau R (1991) Defense mechanisms of conifers, differences in constitutive and wound-induced monoterpene biosynthesis among species. Plant Physiol 96:44-49

Litvak ME, Monson RK (1998) Patterns of induced and constitutive monoterpene production in conifer needles in relation to insect herbivory. Oecologia 114:531-540

Loreto F, Ciccioli P, Cecinato A, Brancaleoni E, Frattoni M, Tricoli D (1996) Influence of environmental factors and air composition on the emission of $\alpha$-pinene from Quercus ilex leaves. Plant Physiol 110:267-275

Loreto F, Forster A, Durr M, Csiky O, Seufert G (1998) On the monoterpene emission under heat stress and on the increased thermotolerance of leaves of Quercus ilex fumigated with selected monoterpenes. Plant Cell Environ 21:101-107

Loreto F, Pinelli P, Manes F, Kollist H (2004) Impact of ozone on monoterpene emissions and evidence for an isoprene-like antioxidant action of monoterpenes emitted byQuercus ilexleaves. Tree Physiol 24:361-367
Loreto F, Barta C, Brilli F, Nogues I (2006) On the induction of volatile organic compound emissions by plants as consequence of wounding or fluctuations of light and temperature. Plant Cell Environ 29:1820-1828

Ludwig SW, Kok LT (2001) Harlequin bug, Murgantia histrionica (Hahn) (Heteroptera: Pentatomidae) development on three crucifers and feeding damage on broccoli. Crop Prot 20:247-251

Mattiacci L, Dicke M, Posthumus MA (1994) Induction of parasitoid attracting synomone in Brussels sprouts plants by feeding of Pieris brassicae larvae: Role of mechanical damage and herbivore elicitor. J Chem Ecol 20:2229-2247

Miles PW (1972) The saliva of Hemiptera. Adv Insect Physiol 9:183-255

Moujahed R, Frati F, Cusumano A, Salerno G, Conti E, Peri E, Colazza S (2014) Egg parasitoid attraction toward induced plant volatiles is disrupted by a non-host herbivore attacking above or belowground plant organs. Front Plant Sci. doi:10.3389/fpls.2014.00601

Müller K, Pelzing M, Gnauk T, Kappea A, Teichmann U, Spindler S, Haferkorn S, Jahn Y Hartmut H (2002) Monoterpene emissions and carbonyl compound air concentrations during the blooming period of rape (Brassica napus). Chemosphere 49:1247-1256

Müller C, van Loon J, Ruschioni S, De Nicola GR, Olsen CE, Iori R, Agerbirk N (2015) Taste detection of the non-volatile isothiocyanate moringin results in deterrence to glucosinolate-adapted insect larvae. Phytochemistry 118:139-148

Palumbo JC, Natwick ET (2010) The Bagrada bug (Hemiptera: Pentatomidae): a new invasive pest of cole crops in Arizona and California. Plant Management Network, http://www.plantmanagementnetwork.org/pub/php/brief/2010/bagrada/. Accessed 30 August 2010

Palumbo JC, Perring TM, Millar JG, Reed DA (2016) Biology, ecology, and management of an invasive stink bug, Bagrada hilaris, in North America. Annu Rev Entomol 61:453-473

Paré PW, Tumlinson JH (1997) De novo biosynthesis of volatiles induced by insect herbivory in cotton plants. Plant Physiol 114:1161-1167

Paris C, Llusia J, Peñuelas J (2010) Changes in monoterpene emission rates of Quecus ilex infested by aphid tended by native or invasive Lasius ant species. J Chem Ecol 36:689-698

Reed DA, Palumbo JC, Perring TM, May C (2013) Bagrada hilaris (Hemiptera: Pentatomidae), an invasive stink bug attacking cole crops in the southwestern United States. J Int Pest Man 4:1-7

Romeo V, Ziino M, Giuffrida D, Condurso C, Verzera (2007) A Flavour profile of capers (Capparis spinosa L.) from the Eolian Archipelago by HS-SPME/GC-MS. Food Chem 101:1272-1278

Roques A, Rabitsch W, Rasplus JY, Lopez-Vaamonde C, Nentwig W, Kenis M (2009) Alien terrestrial invertebrates of Europe. In: Handbook of alien species in Europe. Springer, Netherlands, pp. 63-79

Ruther J, Reinecke A, Hilker M (2002) Plant volatiles in the sexual communication of Melolontha hippocastani : response towards time-dependent bouquets and novel function of (Z)-3-hexen-1-ol as a sexual kairomone. Ecol Entomol 27:76-83

Sánchez-Peña S (2014) First record in Mexico of the invasive stink bug Bagrada hilaris, on cultivated crucifers in Saltillo. Southwest Entomol 39:375-376

Schaefer CW, Panizzi AR (2000) Economic importance of Heteroptera: a general view. Heteroptera of economic importance. CRC Press, Boca Raton, pp. 3-8

Schroeder R, Hilker M (2008) The relevance of background odor in resource location by insects: a behavioral approach. Bioscience 58:308-316

Turlings TCJ, Bernasconi M, Bertossa R, Bigler F, Caloz G, Dorn $\mathrm{S}$ (1998) The induction of volatile emissions in maize by three 
herbivore species with different feeding habits-possible consequences for their natural enemies. Biol Control 11:122-129

Van der Meijden E (1996) Plant defence, an evolutionary dilemma: contrasting effects of (specialist and generalist) herbivores and natural enemies. In Proceedings of the 9th International Symposium on Insect-Plant Relationships, Springer, Netherlands, pp. $307-310$

Velikova V, Salerno G, Frati F, Peri E, Conti E, Colazza S Loreto F (2010) Influence of feeding and oviposition by phytophagous pentatomids on photosynthesis of herbaceous plants. J Chem Ecol 36:629-641

Welter SC (1989) Arthropod impact on plant gas exchange. In: Bernays EA (ed) Insect-Plant Interactions. CRC Press, Boca Raton, pp 135-151
Williams III L, Rodriguez-Saona C, Paré PW, Crafts-Brandner SJ (2005) The piercing-sucking herbivores Lygus hesperus and Nezara viridula induce volatile emission in plants. Arch Insect Biochem 58:84-96

Wiman NG, Walton VM, Shearer PW, Rondon SI (2014) Electronically monitored labial dabbing and stylet 'probing'behaviors of brown marmorated stink bug, Halyomorpha halys, in simulated environments. PLoS One 9(12):e113514

Zhao D, Thang J, Ding X (2007) Analysis of volatile components during potherb mustard (Brassica juncea, Coss.) pickle fermentation using SPME-GC-MS. LWT-Food Sci Technol 40:439-447

Zvereva E, Lanta V, Kozlov M (2010) Effects of sap-feeding insect herbivores on growth and reproduction of woody plants: a metaanalysis of experimental studies. Oecologia 163:949-960

\section{글 Springer}

\begin{tabular}{|l|l|l|l|l|}
\hline Journal : Large 11829 & Article No : 9516 & Pages : 10 & MS Code : APIS-D-16-00014 & Dispatch : 25-3-2017 \\
\hline
\end{tabular}

